\title{
DEMOKRASI PINCANG: ANALISIS TERHADAP INDEKS DEMOKRASI PROVINSI SUMATERA BARAT PASCA REFORMASI
}

\author{
Hidayatul Fajri $^{{ }^{*}}$, Nila Wahyuni ${ }^{2}$, Boni Saputra ${ }^{1}$, Karjuni Dt. Maani ${ }^{1}$ \\ ${ }^{1}$ Jurusan Ilmu Administrasi Negara, Fakultas Ilmu Sosial, Universitas Negeri Padang \\ ${ }^{2}$ Jurusan Administrasi Publik, Fakultas Ilmu Sosial dan Ilmu Politik, Universitas Andalas \\ Email: hidayatulfajri@fis.unp.ac.id
}

\begin{abstract}
Democracy is believed to be the best choice of the modern political system. However, in practice, democracy is often interpreted in a different position from the normative and is often influenced by the practical political environment. Therefore, a measure is needed to be carried out continuously to see whether democracy is moving forward. Indonesia has the Indonesian Democracy Index (IDI) which aims to capture the state of Indonesia's democracy based on data at the provincial level. Our work in this article is to analyze the condition of democracy in West Sumatra Province, which has recently received public attention due to its perceived lack of pluralistic rules. By processing IDI data from 2009 to 2019 in descriptive statistics to take a deeper look at the condition of democracy in West Sumatra, we find that the cause of the low democracy index in West Sumatra is not only caused by regulations that limit freedom or require people to practice their religion which is in the public spotlight but also caused by the dominance of the executive and the weak role of the legislature, especially in terms of initiating policies that are then enacted into regulations. And we hypothesize that the executive often takes advantage of this condition to make populist policies, one of which is the "religious" policies.
\end{abstract}

Keywords: Democracy Index, Civil Liberties, Political Rights, Institutions of Democracy

\begin{abstract}
Abstrak
Demokrasi dipercaya sebagai sebuah pilihan terbaik dari sistem politik modern. Namun begitu di dalam prakteknya, demokrasi seringkali dimaknai dalam posisi yang berbeda dari normatifnya dan seringkali dipengaruhi oleh lingkungan politik praktis. Oleh sebab itu perlu suatu ukuran yang dilakukan secara terus menerus untuk melihat apakah demokrasi tersebut bergerak maju. Indonesia memiliki Indeks Demokrasi Indonesia (IDI) yang bertujuan untuk memotret kondisi demokrasi Indonesia yang berbasis pada data di tingkat provinsi. Pekerjaan kami dalam artikel ini adalah menganalisis kondisi demokrasi di Provinsi Sumatera Barat yang belakangan sering mendapat sorotan publik akibat dianggap memiliki aturan-aturan yang kurang plural. Dengan mengolah data IDI dari tahun 2009 sampai 2019 secara statistik deskriptif, kami berupaya melihat lebih dalam tentang kondisi demokrasi di Sumatera Barat dan mendapati bahwa penyebab rendahnya indeks demokrasi Sumatera Barat bukan saja diakibatkan oleh adanya aturan tertulis yang membatasi kebebasan atau mengharuskan masyarakat dalam menjalankan agamanya yang menjadi sorotan publik namun juga diakibatkan oleh dominasi eksekutif dan lemahnya peran legislatif terutama dalam hal menginisiasi kebijakan yang kemudian ditetapkan menjadi peraturan. Dan kami berhipotesis jika eksekutif sering memanfaatkan kondisi itu untuk membuat kebijakan-kebijakan populis yang salah satunya adalah dengan kebijakan-kebijakan berbau "agamis" tersebut.
\end{abstract}

Kata Kunci: Indeks Demokrasi, Kebebasan Sipil, Hak-hak Politik, Lembaga Demokrasi 


\section{PENDAHULUAN}

Demokrasi saat ini menjadi sebuah wacana yang hampir diterima sebagai suatu konsep ideal di seluruh negara. Fukuyama menyebutnya sebagai "kemenangan demokrasi" pasca runtuhnya Uni Soviet yang membuat demokrasi menjadi pemenang dari pertarungan ideologi dalam perang dingin. Sedangkan Huntington, dalam kajian klasiknya, menyebut fenomena itu sebagai "gelombang demokratisasi".

Namun begitu di tengah "pengagungan" yang terjadi terhadap demokrasi saat ini, pada sisi lain terjadi kemandekan bahkan Larry Diamond (2015) mengistilahkan dengan "democratic recession" atau resesi demokrasi. Saat ini tidak peduli negara dengan rezim politik kiri ataupun kanan mengklaim dirinya sebagai pemerintahan yang demokratis. Dalam bukunya yang lain, Fukuyama (2018) menjelaskan data bahwa pada tahun 1970 hanya ada sekitar 35 negara demokrasi. Namun di tahun 2000an, tiga dekade setelah itu, jumlah negara demokrasi mencapai 120. Di mana penambahan terbanyak datang dari negara-negara bekas Uni Soviet, Eropa Timur, dan negara-negara lain bekas penganut paham komunis. Sehingga banyak dari negara tersebut kemudian mempraktekkan demokrasi yang sebenarnya berbeda dari konsepsi terhadap demokrasi yang ideal.

Artikel ini selanjutnya tidak akan membahas tentang konstelasi demokrasi pada tingkat global ataupun nasional. Sebab tema tersebut sudah menjadi perhatian banyak sarjana politik dan kebijakan publik. Namun tema yang kurang dibahas di dalam literaturliteratur demokrasi adalah tentang bagaimana demokrasi yang terjadi pada tingkat lokal. Sehingga urgensi dari artikel ini adalah tentang, apa yang "sebenarnya" terjadi dengan demokrasi pada tingkat lokal? Apakah yang terjadi pada tingkat lokal juga menunjukkan “demokrasi yang kelelahan”? sehingga kehilangan makna dan konteksnya.

Menjawab rumusan tersebut, kami akan melakukan studi terhadap kasus demokrasi pada tingkat lokal yang terjadi di Provinsi Sumatera Barat pasca reformasi. Hal tersebut dikarenakan dalam beberapa waktu terakhir terjadi sorotan terhadap praktek demokrasi yang terjadi di daerah ini. Seperti permasalahan tentang adanya aturan-aturan yang mewajibkan untuk menjalankan syariat islam, pelarangan pembangunan tempat ibadah atau perayaan ibadah agama-agama minoritas baik yang dilakukan oleh institusi pemerintah ataupun masyarakat, ataupun kekerasan terhadap masyarakat di dalam penyampaian aspirasi. Fenomena ini tentu menarik untuk dianalisis dalam kerangka demokrasi dengan alasan; pertama, Indonesia sebagai suatu negara sudah memiliki track record yang panjang tentang demokrasi walaupun dengan segala dinamikanya secara 
praktis, dan kedua, Provinsi Sumatera Barat, yang mayoritas penduduknya bersuku bangsa Minangkabau, terkenal dengan konsep musyawarah mufakat yang sebenarnya merupakan esensi dari konsep demokrasi.

Di dalam menganalisis fenomena tersebut, kami akan menggunakan data dari Indeks Demokrasi Indonesia (IDI). Data yang ada pada IDI menggambarkan bagaimana kondisi demokrasi yang terjadi di daerah-daerah atau pada tingkat lokal dengan menggunakan indikator-indikator sebagai instrumen pengukuran. Pada artikel ini kami mengambil dan menganalisis data Provinsi Sumatera Barat yang ada sejak tahun 2009 (awal dilakukan pengukuran).

Selanjutnya, sebagai landasan akademik dari artikel ini, kami menyatakan bahwa belum ada studi yang membahas tentang demokrasi lokal yang secara spesifik menggunakan data IDI sebagai unit analisisnya. Adapun literatur-literatur yang tersedia mengenai kajian demokrasi lokal antara lain banyak membahas tentang hubungan dengan etnisitas seperti yang dibahas oleh Ronsumbre (2019), Asrinaldi dan Azwar (2018), Fikri dan Adytyas (2018), Armasnyah (2017), Tini (2017), Haboddin (2012), dan Leni (2012) atau yang berkaitan dengan pemilihan langsung seperti yang ditulis oleh Romli (2018), Suyatno (2016), Sinaga (2013), dan Agustino dan Yusoff (2010) atau tentang dinamika yang terjadi dalam demokrasi lokal yang diteliti oleh Rahmat dan Savirani (2020), Aziz (2019), Fitri (2019), Damayanti, dkk (2017), Amaliatulwalidain (2016), Sarman (2016), Al-Hamdi (2011), dan Asrinaldi (2010).

\section{TELAAH LITERATUR}

\section{Indeks Demokrasi Indonesia (IDI)}

Indeks Demokrasi Indonesia diinisasi oleh Bappenas pada tahun 2008 yang bertujuan untuk mengetahui dan menilai secara reguler apakah kondisi demokrasi Indonesia bergerak menuju negara demokrasi atau justru sebaliknya. Pengukuran tersebut bersumber dari nilai demokrasi yang didapat pada tingkat provinsi di Indonesia. Sehingga, IDI sebenarnya bertujuan untuk mengkuantifikasikan perkembangan dari demokrasi pada tingkat provinsi di Indonesia agar terjadi perencanaan pembangunan politik yang berkelanjutan di Indonesia sekaligus untuk menyelaraskan dengan otonomi daerah. Alasan lainnya dikarenakan oleh peristiwa-peristiwa demokrasi terjadi dan berlangsung di dalam lingkup unit politik daerah ini (IDI, 2019). Manfaat dari IDI yaitu: 1) Memberikan data penting yang dapat dimanfaatkan untuk studi mengenai perkembangan demokrasi di 
Indonesia karena tingkat perkembangan tersebut didasarkan atas data-data yang jelas dengan tolok ukur yang jelas pula, 2) Perencanaan pembangunan politik daerah, 3) Bagi Provinsi yang tingkat perkembangan demokrasinya kurang baik dapat menarik pelajaran dari data-data tersebut dengan memperhatikan indikator-indikator demokrasi yang mendapat nilai rendah. Pemerintah daerah dan masyarakat di provinsi bersangkutan secara bersama-sama dapat mengambil langkah-langkah tertentu yang dapat memperbaiki angka bagi indikator tersebut sehingga indeks bagi indikator itu bisa meningkat di masa yang akan datang (IDI, 2009).

Adapun yang dijadikan sebagai tolok ukur penilaian dari IDI yaitu sistem, mekanisme, dan prosedur (procedural democracy) maupun persolan-persolan yang bersifat substantif seperti kebebasan, keadilan, dan perilaku demokratik atau adab bernegara masyarakat (IDI 2019). Ukuran-ukuran tersebut secara spesifik kemudian dibreakdown menjadi 3 (aspek), yaitu: Kebebasan Sipil, Hak-hak Politik, dan Lembaga Demokrasi. Ketiga aspek tersebut kemudian diukur lagi berdasarkan variabel dan variabel juga dibagi ke dalam indikator. Aspek Kebebasan sipil terdiri dari 4 variabel dan 10 indikator di dalamnya, Hak-hak politik terdiri dari 2 variabel dan 7 indikator, sedangkan Lembaga Demokrasi terdiri dari 5 variabel dan 11 indikator.

Data penilaian IDI didapatkan dari berbagai metodologi antara lain review surat kabar, review dokumen, Focus Group Discussion (FGD) dan wawancara mendalam terhadap sejumlah informan terpilih yang dianggap memiliki pengetahuan yang layak (well informed person) terhadap hal-hal yang diukur di provinsi tempat mereka berdomisili. Data kemudian diolah sedemikan rupa untuk kemudian diskalatisasi 0 - 100 untuk mendapatkan angka yang kemudian dikategorikan menjadi <60 Buruk; 60-80 sedang; dan >80 baik. Adapun sampai tahun 2021 pengukuran terhadap IDI sudah dilakukan sebanyak 11 (sebelas) tahun.

\section{Konsepsi Demokrasi di dalam Indeks Demokrasi Indonesia}

Demokrasi, apalagi sekarang ini, merupakan sebuah kata yang sudah sangat sulit untuk didefiniskan secara utuh untuk memahami realitas sosialnya. Oleh sebab itu perlu untuk mengetahui defenisi operasional yang digunakan di dalam IDI. Walaupun secara tekstual IDI tidak menjelaskan defenisi tentang demokrasi yang digunakan namun dapat dipahami yang dimaksud dengan demokrasi di dalam IDI adalah pola interaksi seimbang yang terjadi antara state dan society. Sebab dijelaskan bahwa untuk memahami demokrasi 
Indonesia maka tidak bisa dilepaskan dari pengaruh rezim Soeharto. Rezim Soeharto merupakan rezim yang menekankan tentang dominasi negara pada banyak hal sehingga tidak memberikan ruang kepada civil society untuk bebas berpartisipasi terutama dalam bidang politik,

Selain itu, IDI juga berupaya untuk mengembangkan Indeks Demokrasi yang dikeluarkan oleh Freedom House. Pengindeksan Freedom House yang didasarkan kepada "indeks kebebasan" kemudian dikembangkan dengan menjadikan 3 aspek yaitu; Kebebasan (Civil Liberty), Hak Politik (Political Rights), dan Lembaga-lembaga Demokrasi (Institutions of Democracy) sebagai acuan penilaian.

Dua aspek yang pertama dan kedua merefleksikan esensi konsep demokrasi. Namun demikian, mengingat dua esensi dasar dari demokrasi tersebut tidak mungkin akan dapat bekerja secara maksimal tanpa adanya "wadah", stuktur, dan prosedur pendukung (IDI, 2009). Maka dengan alasan itu IDI juga menjadikan lembaga-lembaga demokrasi sebagai bagian dari aspek penting demokrasi.

\section{Aspek Kebebasan Sipil (Civil Liberties)}

Pendefenisian aspek ini di dalam IDI merujuk kepada Bealey (2000) yang menjelaskan bahwa konsep civil liberties berkaitan dengan free self-expression, free movement dan freedom from arbitrary arrest. Konsep ini bersandar pada keyakinan bahwa kebebasan merupakan hal yang esensial bagi demokrasi sebab tanpa kebebasan mustahil bagi masyarakat untuk meminta pertanggungjawaban pemerintah.

Namun begitu, kebebasan memiliki spektrum pemahaman yang luas. IDI dalam hal ini merujuk kepada konsep Bealey (2000) tentang elemen dari kebebasan sipil yaitu; 1) Kebebasan untuk mengemukakan pendapat (freedom of expression), kebebasan pers (freedom of press), kebebasan untuk berserikat (freedom of assembly), dan kebebasan untuk berkeyakinan/ beribadah (freedom of worship). Oleh sebab itu dapat defenisi operasional yang dipakai IDI untuk aspek ini yaitu; kebebasan individu/warga negara dan kelompok individu untuk berkumpul dan berserikat, berpendapat, berkeyakinan, serta kebebasan dari diskriminasi dan pengekangan yang berasal dari individu/warga negara lainnya, kekuasaan negara, dan kelompok masyarakat tertentu (IDI, 2009). Meski begitu, IDI memberikan batasan defenisi tersebut dengan menyatakan bahwa kebebasan sipil yang akan dilihat dibatasi hanya pada kekuasaan individu dan kelompok yang berhubungan dengan kekuasaan yang dimiliki oleh negara dan atau kelompok masyarakat tertentu. 
Selain itu, yang dimaksud negara dalam pengertian IDI adalah pemerintah daerah, birokrasi pemerintah daerah, anggota DPRD, anggota DPRP dan MRP (khusus Papua), KPUD, Kepolisian Daerah (Polda). Sedangkan definisi kelompok masyarakat adalah organisasi kemasyarakatan berdasarkan, antara lain, kesamaan agama, etnis, suku, ras, ruang lingkup pekerjaan, dan kesamaan tujuan berkelompok. Adapun variabel yang digunakan untuk menyusun aspek ini yaitu: 1) Kebebasan berkumpul dan berserikat, 2) Kebebasan berpendapat, 3) Kebebasan berkeyakinan, dan 4) kebebasan dari diskriminasi. Sedangkan untuk indikator dari masing-masing variabel dapat dilihat pada tabel 1.

\section{Hak-Hak Politik (Political Rights)}

Hak-hak politik merupakan dimensi demokrasi yang mencakup partisipasi dan kompetisi. Dalam konteks IDI maka hak-hak politik diturunkan ke dalam dua variabel yaitu: 1) Hak memilih dan dipilih, dan 2) Partisipasi politik dalam pengambilan keputusan dan pengawasan. Sementara pada tingkat indikator, Aspek Hak-Hak Politik memiliki tujuh indikator yang terdiri dari: lima indikator pada variabel 1 , dan dua indikator pada variabel 2. Lebih lengkap mengenai indikator dapat dilihat pada tabel 1.

\section{Aspek Lembaga Demokrasi (Institutions of Democracy)}

Lembaga, dalam konteks demokrasi, dapat didefenisikan sebagai institusi-institusi negara yang dibentuk dan berfungsi dalam memastikan terbentuk dan bekerjanya sistem politik yang demokratis. Sehingga yang dimaksud dengan lembaga demokrasi di dalam IDI (2009) dapat berada pada tataran "suprastruktur" - meliputi antara lain, lembaga eksekutif, legislatif, dan yudikatif dan juga "infrastruktur" - seperti misalnya, pemilahan umum (Pemilu), partai politik, pers, dan kelompok kepentingan.

Aspek ini di dalam IDI memiliki 5 (lima variabel) yaitu: 1) Pemilihan umum (Pemilu) yang bebas dan adil, 2) Peran Dewan Perwakilan Rakyat Daerah (DPRD), 3) Peran partai politik, 4) Peran birokrasi pemerintahan daerah, dan 5) Peradilan yang independen. Sedangkan untuk indikator, aspek ini memiliki 11 variabel yang untuk lebih lengkapnya dapat dilihat pada tabel 1.

Tabel 1. Aspek, Variabel, dan Indikator IDI

\begin{tabular}{lll}
\hline \multicolumn{1}{c}{ Aspek } & \multicolumn{1}{c}{ Variabel } & \multicolumn{1}{c}{ Indikator } \\
\hline $\begin{array}{l}\text { Kebebasan } \\
\text { Sipil }\end{array}$ & $\begin{array}{l}\text { Kebebasan Berkumpul } \\
\text { dan berserikat }\end{array}$ & $\begin{array}{l}\text { Ancaman kekerasan atau penggunaan kekerasan oleh } \\
\text { aparat pemerintah yang menghambat kebebasan } \\
\text { berkumpul dan berserikat }\end{array}$ \\
\hline
\end{tabular}




\begin{tabular}{|c|c|c|}
\hline & & $\begin{array}{l}\text { Ancaman kekerasan atau penggunaan kekerasan oleh } \\
\text { masyarakat yang menghambat kebebasan berkumpul } \\
\text { dan berserikat }\end{array}$ \\
\hline & Kebebasan berpendapat & $\begin{array}{l}\text { Ancaman kekerasan atau penggunaan kekerasan oleh } \\
\text { aparat pemerintah yang menghambat kebebasan } \\
\text { berpendapat }\end{array}$ \\
\hline & & $\begin{array}{l}\text { Ancaman kekerasan atau penggunaan kekerasan oleh } \\
\text { masyarakat yang menghambat kebebasan } \\
\text { berpendapat }\end{array}$ \\
\hline & $\begin{array}{l}\text { Kebebasan } \\
\text { berkeyakinan }\end{array}$ & $\begin{array}{l}\text { Aturan tertulis yang membatasi kebebasan atau } \\
\text { mengharuskan masyarakat dalam menjalankan } \\
\text { agamanya }\end{array}$ \\
\hline & & $\begin{array}{l}\text { Tindakan atau pernyataan pejabat Pemerintah yang } \\
\text { membatasi kebebasan atau mengharuskan masyarakat } \\
\text { untuk menjalankan ajaran agamanya }\end{array}$ \\
\hline & & $\begin{array}{l}\text { Ancaman kekerasan atau penggunaan kekerasan oleh } \\
\text { masyarakat karena alasan gender, etnis atau terhadap } \\
\text { kelompok rentan lainnya }\end{array}$ \\
\hline & $\begin{array}{l}\text { Kebebasan dari } \\
\text { diskriminasi }\end{array}$ & $\begin{array}{l}\text { Aturan tertulis yang diskriminatif dalam hal gender, } \\
\text { etnis atau terhadap kelompok rentan lainnya }\end{array}$ \\
\hline & & $\begin{array}{l}\text { Tindakan atau pernyataan pejabat pemerintah daerah } \\
\text { yang diskriminatif dalam hal gender, etnis atau } \\
\text { terhadap kelompok rentan lainnya }\end{array}$ \\
\hline & & $\begin{array}{l}\text { Ancaman kekerasan atau penggunaan kekerasan oleh } \\
\text { masyarakat karena alasan gender, etnis atau terhadap } \\
\text { kelompok rentan lainnya }\end{array}$ \\
\hline \multirow[t]{8}{*}{$\begin{array}{l}\text { Hak-hak } \\
\text { Politik }\end{array}$} & Hak memilih dan dipilih & $\begin{array}{l}\text { Kejadian di mana hak memilih atau dipilih } \\
\text { masyarakat terhambat }\end{array}$ \\
\hline & & $\begin{array}{l}\text { Kejadian yang menunjukkan ketiadaan/kekurangan } \\
\text { fasilitas sehingga kelompok penyandang cacat tidak } \\
\text { dapat menggunakan hak memilih }\end{array}$ \\
\hline & & Kualitas daftar pemilih tetap (DPT) \\
\hline & & $\begin{array}{l}\text { Persentase penduduk yang menggunakan hak pilih } \\
\text { dibandingkan dengan yang memiliki hak untuk } \\
\text { memilih dalam pemilu (voters turnout) }\end{array}$ \\
\hline & & $\begin{array}{l}\text { Persentase perempuan terpilih terhadap total anggota } \\
\text { DPRD provinsi }\end{array}$ \\
\hline & Partisipasi Politik dalam & Persentase demonstrasi/mogok yang bersifat \\
\hline & $\begin{array}{l}\text { Pengambilan Keputusan } \\
\text { dan Pengawasan }\end{array}$ & kekerasan terhadap total demonstrasi/mogok \\
\hline & & $\begin{array}{l}\text { Pengaduan masyarakat mengenai penyelenggaraan } \\
\text { pemerintahan }\end{array}$ \\
\hline \multirow{5}{*}{$\begin{array}{l}\text { Lembaga- } \\
\text { lembaga } \\
\text { Demokrasi }\end{array}$} & $\begin{array}{l}\text { Pemilu yang bebas dan } \\
\text { adil }\end{array}$ & $\begin{array}{l}\text { Kejadian yang menunjukkan keberpihakan KPUD } \\
\text { dalam penyelenggaraan pemilu }\end{array}$ \\
\hline & & $\begin{array}{l}\text { Kejadian atau pelaporan tentang kecurangan dalam } \\
\text { penghitungan suara }\end{array}$ \\
\hline & Peran DPRD & $\begin{array}{l}\text { Besaran alokasi anggaran pendidikan dan kesehatan } \\
\text { per kapita }\end{array}$ \\
\hline & & $\begin{array}{l}\text { Persentase jumlah perda yang berasal dari hak } \\
\text { inisiatif DPRD terhadap jumlah total perda yang } \\
\text { dihasilkan }\end{array}$ \\
\hline & & Rekomendasi DPRD kepada eksekutif \\
\hline
\end{tabular}




\begin{tabular}{ll}
\hline \hline Peran Partai Politik & $\begin{array}{l}\text { Kegiatan kaderisasi yang dilakukan parpol peserta } \\
\text { pemilu }\end{array}$ \\
\hline Peran Birokrasi & $\begin{array}{l}\text { Persentase perempuan dalam kepengurusan parpol } \\
\text { tingkat provinsi }\end{array}$ \\
\hline Pemerintah Daerah & $\begin{array}{l}\text { Laporan dan berita penggunaan fasilitas pemerintah } \\
\text { untuk kepentingan calon/parpol tertentu dalam } \\
\text { pemilu legislatif }\end{array}$ \\
\hline Peran Peradilan yang & $\begin{array}{l}\text { Laporan dan berita keterlibatan PNS dalam kegiatan } \\
\text { politik parpol pada pemilu legislatif }\end{array}$ \\
\hline Keputusan hakim yang kontroversial \\
\hline
\end{tabular}

\section{METODE PENELITIAN}

Penelitian ini dilakukan dengan cara analisis dokumen menggunakan pengukuran statistik deskriptif. Dokumen yang dianalisis berupa dokumen yang Indeks Demokrasi Indonesia yang dirilis setiap tahun sejak tahun 2009 dan terakhir 2019. Adapun dokumen IDI yang kami gunakan diakses dari http://ditpolkom.bappenas.go.id/v2/?page id=856 yang dapat diakses secara terbuka oleh publik. Meski begitu kami tidak mendapatkan data secara lengkap pada dokumen IDI tahun 2017 untuk masing-masing variabel dari masingmasing aspek di tahun 2017 sehingga nilai untuk tahun itu terpaksa kami kosongkan. Selain itu, pada tahun 2015 terjadi penambahan provinsi yang diukur yaitu Provinsi Kalimantan Utara yang menambah jumlah provinsi yang diindeks dari 33 provinsi menjadi 34 provinsi.

\section{HASIL DAN PEMBAHASAN}

\section{Indeks Demokrasi Sumatera Barat}

Tahun 2019 capaian Indeks Demokrasi Provinsi Sumatera Barat berada pada nilai 67,69. Nilai tersebut naik 0,63 poin dari tahun sebelumnya (2018) namun masih kalah dari tahun 2017 dengan nilai 69,5 yang juga merupakan nilai tertinggi yang pernah didapat oleh Provinsi Sumatera Barat dari 11 (sebelas) tahun pengukuran Indeks Demokrasi Indonesia. Nilai tersebut menyatakan bahwa kualitas demokrasi di Sumatera Barat dapat dikelompokkan pada kualitas sedang, yang artinya demokrasi yang ditandai oleh hadir dan berfungsinya sistem dan institusi demokrasi, namun masih menyisakan sejumlah persoalan (IDI 2019).

Meski begitu, Kualitas "sedang" dari demokrasi Sumatera Barat masih memiliki gap yang cukup jauh jika dibandingkan dengan rata-rata nasional. Terlebih dalam 7 (tujuh) 
tahun terakhir (2013 s.d 2019) gap antara indeks demokrasi Sumatera Barat dengan IDI tidak pernah bisa kurang dari 5 poin (atau 5\%) (lihat tabel 2). Bahkan data juga memperlihatkan bahwa indeks demokrasi Sumatera Barat tidak pernah berada di atas IDI. Kondisi itu berimplikasi kepada ranking demokrasi Sumatera Barat apabila dibandingkan dengan provinsi lain. Ranking Sumatera Barat tidak pernah berada di dua puluh besar provinsi dengan nilai demokrasi tertinggi. Ranking paling tinggi yang diraih Sumatera Barat hanya pada posisi 23, bahkan pernah berada di posisi paling akhir (ranking 34) pada tahun 2016.

Tabel 2. Indeks Demokrasi Sumatera Barat

\begin{tabular}{cccccc}
\hline Tahun & Nilai & $\begin{array}{c}\text { Gap dari } \\
\text { Th. } \\
\text { Sebelumnya }\end{array}$ & Ranking & $\begin{array}{c}\text { Rata-rata } \\
\text { Nasional }\end{array}$ & $\begin{array}{c}\text { Gap Nilai } \\
\text { Prov. \& } \\
\text { Nas. }\end{array}$ \\
\hline 2009 & 60,29 & - & 31 & 67,30 & $-7,01$ \\
\hline 2010 & 63,04 & $+2,75$ & 24 & 63,17 & $-0,13$ \\
\hline 2011 & 65,02 & $+1,98$ & 24 & 65,48 & $-0,46$ \\
\hline 2012 & 60,82 & $-4,2$ & 23 & 62,63 & $-1,81$ \\
\hline 2013 & 54,11 & $-6,71$ & 32 & 63,72 & $-9,61$ \\
\hline 2014 & 63,99 & $+9,88$ & 31 & 73,04 & -9.05 \\
\hline 2015 & 67,46 & $+3,47$ & $27 / 34$ & 72,82 & -5.36 \\
\hline 2016 & 54,41 & $-13,05$ & $34 / 34$ & 70,09 & $-15,68$ \\
\hline 2017 & 69,5 & $+15,09$ & $28 / 34$ & 72,11 & $-2,61$ \\
\hline 2018 & 67,06 & $-2,44$ & $30 / 34$ & 72,39 & $-5,33$ \\
\hline 2019 & 67,69 & $+0,63$ & $30 / 34$ & 74,92 & $-7,23$ \\
\hline
\end{tabular}

Di dalam rentang 11 (sebelas) tahun pengukuran, Indeks Demokrasi Sumatera Barat tercatat 9 (sembilan) kali dikategorikan sedang dan 2 (dua) kali dikategorikan rendah, yaitu tahun 2013 dan 2016. Pada ke dua tahun tersebut Indeks Demokrasi Sumatera Barat hanya memperoleh nilai 54,11 dan 54,41. Ke dua tahun tersebut juga menjadi tahun dengan gap tertinggi antara nilai demokrasi Sumatera Barat dengan IDI, yaitu 9,61 poin dan 15,68 poin. Apakah ada kaitan antara pola dari tingginya gap tersebut dengan pelaksanaan Pemilu 2014 dan Pilkada DKI 2017? Untuk mengetahui hal itu tentu memerlukan suatu penelitian tersendiri. Namun data yang ada menunjukkan bahwa pola tersebut tidak terulang di tahun 2018. Meski begitu, jika membandingkan data sejak awal dilakukan pengindeksan dengan data terakhir maka terlihat ada tren positif dari Indeks Demokrasi Sumatera Barat walau nilai terlihat fluktuatif.

Lebih lanjut, kami mencoba untuk menyelidiki nilai dari masing-masing aspek yang menjadi acuan penilaian dari IDI. Seperti yang sudah disinggung sebelumnya, IDI 
menggunakan 3 (aspek) di dalam mengukur Indeks Demokrasi Provinsi yaitu; Kebebasan Sipil, Hak-Hak Politik, dan Lembaga Demokrasi. Data memperlihatkan ada keunikan di dalam Indeks Demokrasi Sumatera Barat, yaitu nilai dari masing-masing aspek memiliki tren yang berbeda-beda (lihat tabel 3).

Tabel 3. Indeks Demokrasi Sumatera Barat Berdasarkan Aspek Penilaian

\begin{tabular}{cccc}
\hline Tahun & Kebebasan Sipil & Hak-hak Politik & $\begin{array}{c}\text { Lembaga } \\
\text { Demokrasi }\end{array}$ \\
\hline 2009 & 63,06 & 53,57 & 67,48 \\
\hline 2010 & 58,34 & 63,9 & 67,59 \\
\hline 2011 & 60,57 & 59,21 & 79,83 \\
\hline 2012 & 57,1 & 50,85 & 81,32 \\
\hline 2013 & 54,88 & 38,97 & 77,17 \\
\hline 2014 & 47,21 & 61,82 & 88,56 \\
\hline 2015 & 52,99 & 69,77 & 82,01 \\
\hline 2016 & 51,01 & 54,33 & 58,82 \\
\hline 2017 & 61,66 & 61,08 & 92,72 \\
\hline 2018 & 55,32 & 62,84 & 88,52 \\
\hline 2019 & 56,58 & 61,06 & 92,21 \\
\hline
\end{tabular}

Pada aspek Kebebasan Sipil, Sumatera Barat memiliki tren nilai yang berada dalam kondisi kategori "rendah". Dari 11 (sebelas) kali pengukuran, Sumatera Barat hanya 3 kali memiliki nilai yang dikategorikan sedang, yaitu tahun 2009, 2011, dan 2017 sedangkan sisanya masuk dalam kategori rendah. Nilai tertinggi di dapat Sumatera Barat pada tahun 2009 dengan 63,06 dan nilai terendah pada tahun 2014 dengan 47,21. Tren dari nilai yang didapat memperlihatkan penurunan dari tahun 2009 sampai 2019.

Pada aspek Hak-hak politik, dari 11 (sebelas) kali penilaian, nilai yang di dapat Sumatera Barat dapat dikategorikan "rendah menuju sedang (low-middle)". Itu terlihat dari 6 (enam) kali nilai yang di dapat Sumatera Barat diketegorikan sedang, namun 5 (kali) lainnya dikategorikan rendah. "Kabar baiknya" dalam 3 (tiga) tahun terakhr nilai yang di dapat berada di posisi sedang, yaitu 61,08, 62,84 dan 61,06. Sedangkan untuk nilai tertinggi untuk aspek ini didapat pada tahun 2010 dengan 63,9 dan nilai terendah didapat pada tahun 2013 dengan 38,97. Tren nilai dari aspek-aspek politik sejak tahun 2009 ke tahun 2019 cenderung naik walaupun terlihat fluktuatif.

Aspek terakhir yaitu lembaga demokrasi. Pada aspek ini, tren nilai Sumatera Barat dapat dikategorikan ke dalam "tinggi". 6 (enam) kali nilai yang didapat berada di atas skor 80, yaitu tahun 2012, 2014, 2015, 2017, 2018, dan 2019. 4 (empat) kali dikategorikan sedang dan sekali dikategorikan rendah. Apalagi 2 (dua) kali dalam 3 (tiga) tahun terakhir 
nilai yang di dapat Sumatera Barat berada di atas skor 90. Selain itu, peningkatan yang terjadi sejak tahun 2009 ke tahun 2019 pun sangat tinggi yaitu 24,73 poin.

Kondisi ini memperlihatkan bahwa demokrasi di Sumatera Barat "berjalan dengan pincang". Sebab pada satu sisi rendah (Kebebasan Sipil) sedangkan di sisi lain tinggi (Lembaga Demokrasi). Perihal ini akan kami bahas lebih lengkap pada sub judul selanjutnya. Sebelum itu, kami akan melihat lebih detail tentang kondisi dari masingmasing aspek agar dapat melihat dengan lebih jelas kondisi demokrasi di Sumatera Barat.

\section{Kebebasan Sipil}

Pada laporan terakhirnya tahun 2019, IDI menyatakan bahwa: “Kekebasan Sipil selalu memperoleh capaian yang tinggi, bahkan yang paling tinggi selama sepuluh tahun pengukuran. Baru tahun ini capaiannya sedikit di bawah aspek Lembaga Demokrasi. Sementara itu dua aspek yang lain capaiannya jauh lebih fluktuatif." Sebab 6 (enam) kali pengukuran, rata-rata Indonesia mendapatkan skor di atas 80. Namun kondisi tersebut bertolak belakang dengan kondisi yang ada di Sumatera Barat. Seperti yang sudah disinggung sebelumnya, tren nilai Sumatera Barat untuk aspek kebebasan sipil dikategorikan rendah. Bahkan gap antara rata-rata nasional dengan Sumatera Barat terdapat gap yang tinggi.

Data memperlihatkan bahwa sejak dimulainya pengukuran, cuma sekali gap berada di bawah 20 poin. Gap tertinggi tercatat pada tahun 2014 dengan 35,41 poin sedangkan yang terendah pada tahun 2017 dengan 17,09 poin. Perbedaan tersebut juga tercermin dari ranking Sumatera Barat terhadap provinsi-provinsi lainnya. Selama 11 (sebelas) tahun Sumatera Barat tidak pernah mendapatkan ranking di bawah 30 bahkan 6 (enam) kali diantaranya berada di posisi paling akhir yaitu tahun 2009, 2010, 2013, 2014, 2016, dan 2018 (lihat tabel 4).

Tabel 4. Aspek Kebebasan Sipil di Sumatera Barat dari tahun 2009 s.d 2019

\begin{tabular}{cccccc}
\hline Tahun & Nilai & $\begin{array}{c}\text { Aspek Kebebasan Sipil } \\
\text { Th. } \\
\text { Sebelumnya }\end{array}$ & Ranking & $\begin{array}{c}\text { Rata-rata } \\
\text { Nasional }\end{array}$ & $\begin{array}{c}\text { Gap Nilai } \\
\text { Prov. \& } \\
\text { Nas. }\end{array}$ \\
\hline 2009 & 63,06 & - & $33 / 33$ & 86,97 & $-23,91$ \\
\hline 2010 & 58,34 & $-4,72$ & $33 / 33$ & 82,53 & $-24,19$ \\
\hline 2011 & 60,57 & $+2,23$ & $30 / 33$ & 80,79 & $-20,22$ \\
\hline 2012 & 57,1 & $-3,47$ & $32 / 33$ & 77,94 & $-20,84$ \\
\hline 2013 & 54,88 & $-2,22$ & $33 / 33$ & 79,00 & $-24,12$ \\
\hline 2014 & 47,21 & $-7,67$ & $33 / 33$ & 82,62 & $-35,41$ \\
\hline 2015 & 52,99 & $+5,78$ & $33 / 34$ & 80,30 & $-27,31$ \\
\hline
\end{tabular}




\begin{tabular}{lccccc}
\hline 2016 & 51,01 & $-1,98$ & $34 / 34$ & 76,45 & $-25,44$ \\
\hline 2017 & 61,66 & $+10,65$ & $33 / 34$ & 78,75 & $-17,09$ \\
\hline 2018 & 55,32 & $-6,34$ & $34 / 34$ & 78,46 & $-23,14$ \\
\hline 2019 & 56,58 & 1,26 & $34 / 34$ & 77,20 & -21.88 \\
\hline
\end{tabular}

Data yang ada tentu mengindikasikan ada persoalan di dalam kebebasan sipil di Sumatera Barat. Oleh sebab itu perlu untuk melihat nilai dari variabel yang ada dalam aspek ini. Ada 4 (empat) variabel yang digunakan yaitu; 1) Kebebasan berkumpul dann berserikan, 2) Kebebasan berpendapat, 3) Kebebasan berkeyakinan dan 4) Kebebasan dari diskriminasi. Dari ke empat variabel tersebut maka variabel kebebasan dari diskriminasi merupakan variabel yang memiliki nilai paling tinggi, yaitu sebanyak 7 (tujuh) kali mendapatkan nilai dengan kategori tinggi (> 80). Berikutnya ada variabel kebebasan berpendapat yang juga 7 (tujuh) kali mendapatkan nilai dengan kategori tinggi (>80) namun pernah sekali mendapatkan nilai dengan kategori rendah yaitu pada tahun 2012 . Sehingga dapat dikatakan bahwa Sumatera Barat tidak terlalu bermasalah di dalam kebebasan sipil jika dilihat dari tren nilai yang didapat oleh variabel kebebasan berpendapat dan kebebasan dari diskriminasi.

Sayangnya, ada 2 (dua) variabel yang tersisa terlihat memiliki tren nilai yang rendah. Pertama yaitu variabel kebebasan berkumpul dan berserikat. Meskipun selama 11 tahun pengukuran (kecuali tahun 2017 data tidak ditemukan) mendapatkan 7 (tujuh) kali kategori tinggi, bahkan sempat dua kali mendapatkan nilai sempurna (100) yaitu tahun 2015 dan 2016. Namun, terjadi tren penurunan yang sangat drastis dalam dua tahun terakhir. Ketika kami melihat lebih detail lagi pada nilai indikatornya maka kami mendapati pada dua tahun terakhir terjadi penurunan yang sangat tinggi. Indikator 1) Ancaman kekerasan atau penggunaan kekerasan oleh aparat pemerintah yang menghambat kebebasan berkumpul dan berserikat hanya mendapatkan nilai 50 pada tahun 2018 dan nilai 0 pada tahun 2019 padahal indikator ini masih mendapatkan nilai 100 pada tahun 2016. Sedangkan indikator 2) Ancaman kekerasan atau penggunaan kekerasan oleh masyarakat yang menghambat kebebasan berkumpul dan berserikat terjadi penuruan pada tahun 2019 yaitu dengan nilau 37,50 dari sebelumnya pada tahun 2018 mendapat nilai 100.

Namun, permasalahan terbesar pada kebebasan sipil di Sumatara Barat terletak pada variabel kebebasan berkeyakinan. Sejak awal pengukuran terlihat bahwa nilai dari kebebasan berkeyakinan selalu pada kategori rendah (lihat tabel 5). Bahkan jika melihat nilai yang didapat Sumatara Barat tidak pernah berada di atas skor 50. Nilai tertinggi yang 
didapat hanya 45,91 pada tahun 2009 dan 2010 sedangkan yang terendah dengan nilai 24,06 pada tahun 2014.

Tabel 5. Nilai dari Variabel-variabel Kebebasan Sipil

\begin{tabular}{ccccc}
\hline Tahun & $\begin{array}{c}\text { Kebebasan } \\
\text { Berkumpul dan } \\
\text { berserikat }\end{array}$ & $\begin{array}{c}\text { Kebebasan } \\
\text { berpendapat }\end{array}$ & $\begin{array}{c}\text { Kebebasan } \\
\text { berkeyakinan }\end{array}$ & $\begin{array}{c}\text { Kebebasan } \\
\text { dari } \\
\text { Diskriminasi }\end{array}$ \\
\hline 2009 & 91,25 & 91,67 & 45,91 & 83,91 \\
\hline 2010 & 12,50 & 86,12 & 45,91 & 93,47 \\
\hline 2011 & 98,75 & 90 & 36,93 & 93,47 \\
\hline 2012 & 98,75 & 58,35 & 36,02 & 93,47 \\
\hline 2013 & 98,75 & 89,98 & 27,20 & 93,47 \\
\hline 2014 & 90 & 91,65 & 24,06 & 71,47 \\
\hline 2015 & 100 & 77,23 & 26,63 & 93,38 \\
\hline 2016 & 100 & 86,12 & 31,12 & 68,72 \\
\hline 2017 & $\mathrm{~N} / \mathrm{A}$ & $\mathrm{N} / \mathrm{A}$ & $\mathrm{N} / \mathrm{A}$ & $\mathrm{N} / \mathrm{A}$ \\
\hline 2018 & 56,25 & 100 & 36,08 & 77,28 \\
\hline 2019 & 4,69 & 77,23 & 45,20 & 96,53 \\
\hline
\end{tabular}

Selanjutnya, kami melihat nilai dari masing-masing indikator yang digunakan agar mendapatkan gambaran yang lebih detail dari variabel kebebasan berkeyakinan di Sumatera Barat. Dari 3 (tiga) indikator terlihat bahwa indikator "Tindakan atau pernyataan pejabat Pemerintah yang membatasi kebebasan atau mengharuskan masyarakat untuk menjalankan ajaran agamanya" dan Indikator "Ancaman kekerasan atau penggunaan kekerasan dari satu kelompok masyarakat terhadap kelompok masyarakat lain terkait dengan ajaran agama", relative memiliki nilai yang cukup tinggi. Indikator "Tindakan atau pernyataan pejabat Pemerintah yang membatasi kebebasan atau mengharuskan masyarakat untuk menjalankan ajaran agamanya" pada dua tahun terakhir (2018 dan 2019) mendapatkan nilai 75,00 dan 78,13. Walaupun pada tahun 2012 sampai dengan 2015 mendapatkan kategori rendah karena mendapat poin di bawah 60 tetapi sisanya mereka mendapat lima kali kategori sedang (termasuk tahun 2018 dan 2019) dan sekali mendapatkan nilai 100 (tahun 2011).

Sedangkan untuk indikator "Ancaman kekerasan atau penggunaan kekerasan dari satu kelompok masyarakat terhadap kelompok masyarakat lain terkait dengan ajaran agama" jauh lebih baik, tercatat delapan kali mendapatkan kategori tinggi bahkan empat kali mendapatkan nilai 100 (2014, 2015, 2016 dan 2019) dan hanya dua kali masuk dalam kategori buruk (2011 dan 2013). Adapun indikator yang paling mendapat nilai terendah di dalam variabel kebebasan berkeyakinan yaitu indikator "Aturan tertulis yang membatasi kebebasan atau mengharuskan masyarakat dalam menjalankan agamanya". Bahkan 
indikator ini sejak tahun 2009, secara konsisten selalu mendapatkan nilai di bawah 35 yang berdampak kepada nilai dari variabel kebebasan sipil.

Sehingga, hal ini menjelaskan masalah utama di dalam variabel kebebasan sipil di Sumatera barat adalah adanya aturan tertulis yang membatasi atau mengharuskan masyarakat dalam menjalankan agamanya. Aturan tertulis tersebut dapat berupa Peraturan Daerah ataupun kebijakan eksekutif baik Peraturan Gubernur ataupun Bupati/Walikota. Namun begitu, kami tidak memiliki data untuk melihat lebih jauh tentang jumlah dan bentuk aturan tertulis yang ada di Sumatera Barat dalam membatasi atau mengharuskan masyarakat dalam menjalankan agama.

\section{Hak-hak Politik}

Aspek hak-hak politik merupakan aspek yang secara konsisten menjadi aspek dengan nilai terendah secara nasional dibandingkan dengan aspek lainnya. Pada lima tahun pertama (2009 s.d 2013) nilai untuk aspek hak-hak politik dikategorikan "rendah" dan baru pada tahun 2014 s.d 2019 masuk pada kategori "sedang”. Kondisi secara nasional tersebut sebenarnya tidak jauh berbeda dengan kondisi di Sumatera Barat. Hingga 2019, Sumatera Barat baru sebanyak enam kali mendapatkan kategori "sedang" dengan tiga diantaranya pada 3 (tiga) tahun terakhir. Meskipun jika melihat ranking secara nasional, Sumatera Barat pada tahun 2009 dan 2010 masuk ke dalam lima besar nasional namun setelah itu nilai yang didapat berada di bawah nilai nasional yang mengakibatkan ranking Sumatera Barat pun melorot.

Tabel 6. Aspek Hak-hak Politik Sumatera Barat dari tahun 2009 s.d 2019

\begin{tabular}{cccccc}
\hline Tahun & Nilai & $\begin{array}{c}\text { Aspek Hak-Hak politik } \\
\text { Gap dari } \\
\text { Th. } \\
\text { Sebelumnya }\end{array}$ & Ranking & Rata-rata & $\begin{array}{c}\text { Gap Nilai } \\
\text { Prov. \& } \\
\text { Nas. }\end{array}$ \\
\hline 2009 & 53,57 & - & 12 & 54,60 & $-1,03$ \\
\hline 2010 & 63,9 & $+10,33$ & 3 & 47,87 & $+16,03$ \\
\hline 2011 & 59,21 & $-4,69$ & 5 & 47,87 & $+11,34$ \\
\hline 2012 & 50,85 & $-8,36$ & 11 & 46,33 & $+4,52$ \\
\hline 2013 & 38,97 & $-11,88$ & 28 & 46,25 & $-7,28$ \\
\hline 2014 & 61,82 & $+22,85$ & 21 & 63,72 & $-1,9$ \\
\hline 2015 & 69,77 & $+7,95$ & 11 & 70,63 & $-0,86$ \\
\hline 2016 & 54,33 & $-15,44$ & 32 & 70,11 & $-15,78$ \\
\hline 2017 & 61,08 & $+6,75$ & 26 & 66,63 & $-5,55$ \\
\hline 2018 & 62,84 & $+1,76$ & 20 & 65,79 & $-2,95$ \\
\hline 2019 & 61,06 & $-1,78$ & 28 & 70,71 & $-9,65$ \\
\hline
\end{tabular}


Lebih lanjut, kondisi dari hak-hak politik Sumatera Barat dapat terlihat lebih detail pada variabel-variabel yang diukur. Dari dua indikator yang diukur menunjukkan bahwa pada kedua variabel "Hak memilih dan dipilih" maupun variabel "Partisipasi politik dalam pengambilan keputusan dan pengawasan" sama-sama menunjukkan kondisi yang tidak cukup baik. Variabel Hak memilih dan dipilih mendapatkan nilai dari tahun 2009 sampai tahun 2013 berada pada kategori rendah, baru semenjak tahun 2014 sampai 2019 perolehan nilai masuk ke dalam kategori "sedang". Begitupun dengan variabel "Partisipasi politik dalam pengambilan keputusan dan pengawasan" hanya tiga kali mendapatkan nilai pada kategori sedang yaitu tahun 2010, 2011, dan 2015. Hanya saja pada variabel "Hak memilih dan dipilih" tren nilai cenderung naik sedangkan pada variabel "Partisipasi Politik dalam Pengambilan Keputusan dan Pengawasan" tren nilainya cenderung fluktuatifmenurun.

Tabel 7. Nilai dari Variabel-variabel Hak-hak Politik

\begin{tabular}{ccc}
\hline Tahun & Hak Memilih dan Dipilih & $\begin{array}{c}\text { Partisipasi Politik dalam } \\
\text { Pengambilan Keputusan dan } \\
\text { Pengawasan }\end{array}$ \\
\hline 2009 & 50,76 & 56,39 \\
\hline 2010 & 50,76 & 77,05 \\
\hline 2011 & 50,76 & 67,66 \\
\hline 2012 & 50,76 & 50,95 \\
\hline 2013 & 50,76 & 27,17 \\
\hline 2014 & 73,63 & 50 \\
\hline 2015 & 73,71 & 65,83 \\
\hline 2016 & 74,12 & 34,53 \\
\hline 2017 & $\mathrm{~N} / \mathrm{A}$ & $\mathrm{N} / \mathrm{A}$ \\
\hline 2018 & 74,12 & 51,56 \\
\hline 2019 & 74,87 & 47,25 \\
\hline
\end{tabular}

\section{Lembaga Demokrasi}

Lembaga demokrasi merupakan aspek dari demokrasi Sumatera Barat yang berdasarkan penilaian IDI berkinerja paling baik semenjak awal pengukuran. Nilai yang didapat hampir selalu berada di atas rata-rata nasional, kecuali tahun 2016 yang juga merupakan tahun di mana Sumatara Barat mendapatkan nilai dengan kategori "buruk". Tercatat, Sumatara Barat 6 (enam) kali mendapatkan nilai dengan kategori baik, yaitu 2012, 2014, 2015, 2017, 2018, dan 2019. Bahkan pada 3 (tiga) tahun terakhir Sumatera Barat masuk ke dalam tiga besar nasional dengan nilai aspek Lembaga Demokrasi tertinggi secara nasional dan berada pada posisi pertama pada tahun 2019 (lihat tabel 8). 
Tabel 8. Aspek Lembaga Demokrasi Sumatera Barat dari Tahun 2009 s.d 2019

\begin{tabular}{cccccc}
\hline Tahun & Nilai & $\begin{array}{c}\text { Aspek Lembaga Demokrasi } \\
\text { Gap dari } \\
\text { Th. } \\
\text { Sebelumnya }\end{array}$ & Posisi & Rata-rata & $\begin{array}{c}\text { Gap Nilai } \\
\text { Prov. \& } \\
\text { Nas. }\end{array}$ \\
\hline 2009 & 67,48 & - & 13 & 62,72 & $+4,76$ \\
\hline 2010 & 67,59 & $+0,11$ & 15 & 63,11 & $+4,48$ \\
\hline 2011 & 79,83 & $+12,27$ & 13 & 74,72 & $+5,11$ \\
\hline 2012 & 81,32 & $+1,49$ & 10 & 69,28 & $+12,04$ \\
\hline 2013 & 77,17 & $-4,15$ & 8 & 72,24 & $+4,93$ \\
\hline 2014 & 88,56 & $+11,39$ & 5 & 75,81 & $+12,75$ \\
\hline 2015 & 82,01 & $-6,55$ & 5 & 66,87 & $+15,14$ \\
\hline 2016 & 58,82 & $-23,19$ & 29 & 62,05 & $-3,43$ \\
\hline 2017 & 92,72 & $+33,9$ & 2 & 72,49 & $+20,23$ \\
\hline 2018 & 88,52 & $-4,2$ & 3 & 75,25 & $+13,27$ \\
\hline 2019 & 92,21 & $+3,69$ & 1 & 78,73 & +13.48 \\
\hline
\end{tabular}

Jika melihat lebih detail pada nilai tiap-tiap variabel yang ada di dalam lembaga demokrasi maka terlihat dari kelima variabel yang ada maka 4 (empat) variabel hampir secara konsisten mendapatkan nilai pada kategori baik. Variabel-variabel itu yaitu; Pemilu yang bebas dan adil, peran partai politik, peran birokrasi pemerintah daerah dan peran peradilan yang independen. Variabel Pemilu yang bebas dan adil semenjak awal pengukuran selalu berada pada kategori baik bahkan dengan nilai selalu di atas 90 dengan 4 (empat) kali di antaranya mendapatkan nilai 100. Hampir sama dengan variabel pemilu yang bebas dan adil, variabel Peran peradilan yang independen juga hampir setiap tahun mendapatkan nilai dengan kategori baik, kecuali tahun 2016.

Tabel 9. Nilai dari Variabel-variabel Lembaga Demokrasi

\begin{tabular}{cccccc}
\hline Tahun & $\begin{array}{c}\text { Pemilu } \\
\text { yang Bebas } \\
\text { dan Adil }\end{array}$ & $\begin{array}{c}\text { Peran } \\
\text { DPRD }\end{array}$ & $\begin{array}{c}\text { Peran } \\
\text { Partai } \\
\text { Politik }\end{array}$ & $\begin{array}{c}\text { Peran } \\
\text { Birokrasi } \\
\text { Pemerintah } \\
\text { Daerah }\end{array}$ & $\begin{array}{c}\text { Peran } \\
\text { Peradilan } \\
\text { yang } \\
\text { Independen }\end{array}$ \\
\hline 2009 & 97,47 & 28,15 & 29,98 & 87,08 & 95,45 \\
\hline 2010 & 97,47 & 44,89 & 7,43 & 87,08 & 95,45 \\
\hline 2011 & 97,47 & 45,82 & 97,45 & 87,08 & 95,45 \\
\hline 2012 & 97,47 & 38,47 & 97,93 & 87,08 & 95,45 \\
\hline 2013 & 97,47 & 39,55 & 61,43 & 87,08 & 95,45 \\
\hline 2014 & 100 & 41,92 & 100 & 100 & 100 \\
\hline 2015 & 100 & 22,53 & 100 & 87,97 & 100 \\
\hline 2016 & 100 & 43,57 & 22,78 & 34,59 & 8,33 \\
\hline 2017 & $\mathrm{~N} / \mathrm{A}$ & $\mathrm{N} / \mathrm{A}$ & $\mathrm{N} / \mathrm{A}$ & $\mathrm{N} / \mathrm{A}$ & $\mathrm{N} / \mathrm{A}$ \\
\hline 2018 & 100 & 68,05 & 100 & 77,15 & 100 \\
\hline 2019 & 90,28 & 79,04 & 100 & 90,38 & 100 \\
\hline
\end{tabular}


Kemudian, variabel selanjutnya yang mendapatkan nilai relatif baik adalah Peran Birokrasi Pemerintah Daerah. Variabel ini selama pengukuran yang dilakukan mendapatkan 8 (delapan) kali kategori baik, satu kali mendapatkan kategori sedang dan rendah. Variabel selanjutnya yang secara nilai memperlihatkan progresi baik yaitu Peran Partai Politik. Meskipun nilai yang didapatkan oleh variabel ini pada dua tahun awal (2009 dan 2010) sangat rendah namun pada tahun-tahun berikutnya mendapatkan nilai yang relative baik, kecuali pada tahun 2016. Bahkan, 4 (kali) mendapatkan nilai sempurna yaitu pada tahun 2014, 2015, 2018, dan 2019.

Satu-satunya variabel pada aspek Lembaga Demokrasi di Provinsi Sumatera Barat yang memperlihatkan kinerja kurang baik adalah Peran DPRD. Terlihat bahwa nilai yang didapat variabel ini baru pada dua tahun terakhir (2018 dan 2019) masuk pada kategori sedang setelah sebelumnya selalu berada pada kategori rendah. Kondisi ini memperlihatkan bahwa di Provinsi Sumatera Barat, baik pada tingkat provinsi maupun kabupaten/kota DPRD bisa dikatakan belum menjalankan fungsinya dengan baik. Kondisi yang tentu sangat disayangkan di dalam iklim demokrasi dan otonomi yang ada di Indonesia, harusnya DPRD menjadi salah satu pilar utama di dalam memperkuat demokrasi.

\section{Demokrasi yang Pincang: Dominannya Eksekutif dan Lemahnya Legislatif}

Jika melihat sekilas dari sisi variabel maka demokrasi di Sumatera Barat, seperti yang sudah disinggung sebelumnya, memperlihatkan kondisi yang paradoksial yaitu rendah pada satu sisi namun tinggi pada sisi yang lain. Namun yang mengejutkan ketika kami mencoba untuk menelaah ke dalam indikator-indikator yang ada maka kami seperti mendapatkan sebuah hubungan yang dapat menggambarkan penyebab kondisi itu terjadi. Langkah yang kami lakukan sederhana yaitu dengan melakukan reduksi data dengan membuat daftar dari 28 indikator yang mendapatkan nilai dalam kategori rendah sebanyak enam kali. Alasan adalah untuk melihat konsistensi dari nilai yang didapat dalam 11 tahun pengkuran dan jika mendapatkan sama dengan 6 atau di atas 6 kali maka menunjukkan bahwa indikator demokrasi di Sumatera Barat tersebut cukup bermasalah. Berikut pada tabel 10 kami mengelompokkan indikator-indikator yang mendapatkan lima kali nilai dalam kategori rendah. 
Tabel 10. Indikator dengan lima kali pengukuran dalam kategori rendah

\begin{tabular}{llll} 
No & \multicolumn{1}{c}{ Indikator } & \multicolumn{2}{c}{ Keterangan } \\
\hline 1 & Aturan tertulis yang membatasi kebebasan atau mengharuskan & 10 Kali masuk \\
& masyarakat dalam menjalankan agamanya & kategori rendah \\
\hline 2 & Persentase perempuan terpilih terhadap total anggota & 10 Kali masuk \\
& DPRD provinsi & kategori rendah \\
\hline 3 & Pengaduan masyarakat mengenai penyelenggaraan pemerintahan & $10 \quad$ Kali masuk \\
& & kategori rendah \\
\hline 4 & Persentase jumlah perda yang berasal dari hak inisiatif DPRD & 10 Kali masuk \\
& terhadap jumlah total perda yang dihasilkan & kategori rendah \\
\hline 5 & Rekomendasi DPRD kepada eksekutif & 10 Kali masuk \\
& & kategori rendah
\end{tabular}

Tabel 10 memperlihatkan bahwa ada satu indikator dari aspek kebebasan sipil, dua indikator dari aspek hak-hak politik dan dua aspel dari aspek lembaga demokrasi yang mendapatkan nilai rendah selama 10 kali penilaian IDI yang dilakukan. Artinya, ke lima indikator tersebut secara konsisten selalu mendapatkan nilai rendah sejak awal mula penilaian. Walaupun jika dicermati angka yang didapat ada sedikit progres namun tidak terlalu signifikan.

Selain itu, jika selama ini persepsi publik tentang penyebab dari rendahnya indeks demokrasi Sumatera Barat dikarenakan oleh adanya aturan-aturan tertulis yang membatasi kebebasan atau mengharuskan masyarakat dalam menjalankan agamanya entah itu lewat peraturan daerah atau peraturan eksekutif lainnya seperti Peraturan Gubernur, Peraturan Bupati ataupun Walikota maka itu hanya menggambarkan satu kondisi saja. Padahal terdapat kondisi-kondisi lain yang berkontribusi terhadap nilai dari Indeks Demokrasi Sumatera Barat yang tidak terlalu baik.

Namun begitu, seperti yang sudah kami sampaikan, apabila dicermati maka terdapat hubungan di antara indikator-indikator tersebut yaitu permasalahan di dalam lembaga penyelenggaraan pemerintahan baik itu eksekutif maupun legislatif dan terutama hubungan di antara ke duanya. Hal tersebut terlihat secara implisit di dalam indikator-indikator bernilai rendah tersebut.

Performa dari rendahnya kinerja eksekutif dapat dilihat dari indikator pengaduan masyarakat mengenai penyelenggaran pemerintahan. Kondisi ini menandakan dua hal, pertama, bahwa eksekutif baik itu provinsi ataupun kabupaten (dalam indeks ini tidak 
menjelaskan dengan rinci lokus dari penyelenggara pemerintahnya) tidak memiliki kinerja yang memuaskan sehingga tingginya tingkat aduan masyarakat; kedua, mereka cenderung tidak responsif dalam menanggapi aduan masyarakat karena setiap tahun mendapatkan indeks yang rendah.

Hal yang sama juga terjadi di pihak legislatif. Rendahnya performa mereka (baik itu di tingkat provinsi ataupun kabupaten) terlihat dari rendahnya indikator Rekomendasi DPRD kepada eksekutif. Kondisi ini mengindikasikan bahwa DPRD tidak memiliki inisiatif yang cukup baik di dalam menjalankan perannya. Sebab, di dalam sistem demokrasi seharusnya legislatif atau parlemen harus memiliki peran yang kuat yang bahkan sama kuatnya dengan eksekutif dalam menginisiasi suatu kebijakan.

Sedangkan dari hubungan di antara kedua lembaga tersebut kami sampai pada suatu analisis yang melihat bahwa sistem demokrasi pasca reformasi atau pasca Soeharto dan semangat otonomi daerah yang menjadi salah satu nafas utama dari reformasi yang sudah terjadi lebih dari dua dekade belum mampu mewujudkan sistem pemerintahan yang seimbang antara eksekutif dan legislatif. Eksekutif cenderung lebih memiliki peran yang dominan dibandingkan legislatif di dalam menginisiasi suatu peraturan atau kebijakan. Kondisi inilah yang membuat penyelenggaraan pemerintahan menjadi pincang dan apabila dikaitkan dengan sistem demokrasi Indonesia yang menggunakan pemilihan langsung, maka tidak mengherankan eksekutif lebih mengeksploitasi peraturan-peraturan / kebijakankebijakan yang populer bagi masyarakat pemilihnya. Salah satunya adalah peraturanperaturan yang berbentuk "syariah" di Sumatera Barat yang memang memiliki nafas islam yang kental.

\section{KESIMPULAN}

Demokrasi merupakan salah satu agenda yang paling esensial diperjuangkan pada saat reformasi di Indonesia. Namun, dua dekade pasca reformasi beberapa aspek masih sangat perlu untuk diperbaiki terutama dalam segi kualitasnya. Di Sumatera Barat, seperti yang sudah dibahas, demokrasi secara eksplisit terlihat sangat bermasalah pada aspek kebebasan sipil dan sedikit bermasalah pada aspek hak-hak politik. Namun, jika ditelaah lebih jauh maka kami mengindikasikan permasalahan demokrasi di Sumatera Barat terletak pada performa dari eksekutif dan legislatif dan hubungan di antara keduanya. Solusinya adalah dengan memperkuat legislatif secara kelembagaan dan menjadikan legislatif kembali ke fungsi esensinya di dalam demokrasi yaitu sebagai "watch dog". Selain itu, memperkuat demokrasi di Sumatera Barat dapat juga dilakukan dengan memperkuat civil 
society atau masyarakat sipil (Fajri, et al 2018; 2020) khususnya di dalam perumusan kebijakan. Agar tercipta poros ketiga yang dapat menjadi penyeimbang agar tercipta iklim demokrasi yang sehat. Namun, hal ini perlu gerakan advokatif dari civil society di Sumatera Barat agar mereka dapat dilibatkan di dalam pembuatan kebijakan.

\section{DAFTAR PUSTAKA}

Agustino, Leo. Yusoff, Mohammad Agus. 2010. Pilkada dan Pemekaran Daerah dalam Demokrasi Lokal di Indonesia: Local Strongmen dan Roving Bandits. Jebat: Malaysian Journal of History, Politics \& Strategic Studies. Vol. 37. hal 86-104.

Al Hamdi, Ridho. 2011. Praktek Demokrasi Lokal di Indonesia: Studi Kasus di Kabupaten Lampung Tengah. Jurnal Studi Pemerintahan. Vol. 2, No.2. hal 355-377.

Amaliatulwalidain. DEMOKRASI LOKAL DI SUMATERA BARAT: Memahami Pendekatan "Self Governing Community" Pada Sistem Pemerintahan Nagari Modern di Minangkabau. Jurnal Pemerintahan \& Politik. Vol. 2, No. 1. hal 1-8.

Armansyah, Yudi. 2017. Kontribusi Seloko Adat Jambi Dalam Penguatan Demokrasi Lokal. Sosial Budaya. Vol. 14, No. 1. hal 1-13.

Asrinaldi. 2010. Penguatan Peran Negara dalam Implementasi Demokrasi Lokal di Indonesia. Unisia. Vol. 60. hal 226-239.

Aziz, Nana Abdul. 2019. Desentralisasi dan Kompleksitas Masalah Demokrasi Lokal. Konferensi Nasional Ilmu Administrasi. Vol. 3 No. 1.

Damayanti , R., Gustomy, R., \& Haboddin, M. 2017. Demokrasi di Malang Menggali Kontribusi Masyarakat Sipil Dalam Pengembangan Demokrasi Lokal. JIP (Jurnal Ilmu Pemerintahan): Kajian Ilmu Pemerintahan Dan Politik Daerah. Vol. 2, No. 1. hal 19-36.

Diamond, Larry. 2015. Facing Up to The Democratic Recession. Journal of Democracy. Vol. 26. No. 1. hal 141-155.

Fajri, H. Nurhabibi, P. Saputra, B. \& Yuanjaya, P. 2020. Community Engagement in a Social Movement: A Case of Geothermal Energy Development in Gunung Talang - Bukit Kili Area. IOP Conference Series: Earth and Environmental Science, 448, 012020 .

Fajri, Hidayatul. Pebrial Ilham, Qori \& Halawa, Historis Soterman. 2018. Analysis of civil society movements: the case of construction of geothermal power plant in Mount Talang Area. E3S Web of Conferences 74, 03003. 
Fikri, Muhammad Siradjudin. Adytyas, Nico Oktario. 2018. Politik Identitas dan dan penguatan Demokrasi Lokal (Kekuatan Wong kito dalam demokrasi lokal). Tamaddun: Jurnal Kebudayaan dan Sastra Islam. Vol. 18, No. 2. hal 167-181.

Fitri, Adelia. 2019. Dinasti Politik pada Pemerintahan di Tingkat Lokal. Kemudi: Jurnal Ilmu Pemerintahan. Vol 4, No. 1. hal 91-111.

Fukuyama, Francis. 2018. Identity: The Demand for Dignity and the Politics of Resentment. New York: Farrar, Straus and Giroux.

Haboddin, Muhtar. 2012. Menguatnya Politik Identitas di Ranah Lokal. Jurnal Studi Pemerintahan. Vol. 3, No.1. hal 116-134.

Leni, Nurkhasanah. 2012. Demokrasi Dan Budaya Politik Lokal Di Jawa Timur Menurut R. Zuhro, Dkk. Tapis. Vol. 8, No. 1. hal 20-39.

Rahmat, Ammar. Savirani, Amalinda. 2020. Social Movement Ala Seniman Kota Yogyakarta Dalam Meramaikan Kontestasi Demokrasi Lokal. Journal of Governance and Social Policy. Vol. 1, No. 2. hal 130-149.

Romli, Lili. 2018. Pilkada Langsung, Calon Tunggal, dan Masa Depan Demokrasi Lokal. Jurnal Penelitian Politik. Vol. 15, No. 2. hal 143-160.

Ronsumbre, Nelwan. 2019. Sistem Noken Papua: Manifestasi Demokrasi Berbasis Kearifan Lokal. Sospol. Vol. 5, No. 2. hal 261-276.

Sarman, Mukhtar. 2016. Kontribusi Peran Politik Tuan Guru Dalam Demokrasi Lokal Di Kalimantan Selatan. Seminar Nasional Politik dan Kebudayaan Departemen Antropologi, FISIP, Universitas Padjadjaran 24-25 Oktober 2016, 90-101.

Sinaga, Rudi Salam. 2013. Implikasi Distorsi Demokrasi Pada Pemilukada Terhadap Penguatan Demokrasi Lokal. Perspektif. Vol. 2, No. 1. hal 47-56.

Suyatno. 2016. Pemilihan Kepala Daerah (Pilkada) dan Tantangan Demokrasi Lokal di Indonesia. Indonesia Political Science Review. Vol 1, No 2. hal 212-230.

Tini, Dwi Listia Rika. 2017. RELASI BUDAYA POLITIK DI MADURA TERHADAP DEMOKRASI LOKAL: Analisis Reformasi Birokrasi dan Pemilihan Kepala Desa. Public Corner. Vol. 12, No. 2. hal 9-25. 